\title{
FAJKI ORAZ SPOSOBY UŻYWANIA TYTONIU NA OBSZARZE OBECNYCH ZACHODNICH ZIEM POLSKICH OD XVII DO POCZĄTKU XX W.
}

\author{
PIPES AND TOBACCO USE IN WESTERN AREAS \\ OF PRESENT-DAY POLAND IN THE PERIOD BETWEEN \\ THE 17TH AND THE BEGINNING OF 20TH CENTURY
}

\author{
(autoreferat wygłoszony w trakcie obrony pracy doktorskiej \\ w dniu 5 listopada $2010 \mathrm{r}$.)
}

\begin{abstract}
Głównym moim celem było opracowanie katalogu fajek znajdowanych w trakcie badań archeologicznych na terenie zachodnich ziem polskich: Pomorza Zachodniego, Pomorza Gdańskiego, zachodniej Wielkopolski, ziemi lubuskiej, Kujaw oraz Śląska. Chodziło o szczegółowy opis materiału, jego analizę chronologiczną oraz wskazanie miejsca produkcji. Badania miały pozwolić na uzyskanie jak najpełniejszych danych nie tylko o samym materiale i popularności, jaką cieszyło się użytkowanie tytoniu, ale również uwidocznić pozycję tej używki w życiu codziennym ówczesnych mieszkańców terenów objętych analizą. W pracy starałem się również przedstawić aspekt społeczny palenia tytoniu oraz handlowy, obrazujący rozprzestrzenianie się fajek na omawianym przeze mnie obszarze.

Pracę swoją podzieliłem na siedem rozdziałów. Pierwsze trzy rozdziały mają charakter wprowadzający. W rozdziale pierwszym pod tytułem „Historia fajki i tytoniu” opisuję genezę pojawienia się zwyczaju palenia w Europie, w tym Polsce. Sam tytoń pojawia się na kontynencie europejskim dopiero w czasach nowożytnych, jednak niektóre znaleziska archeologiczne, jak również źródła pisane z czasów antycznych pozwalają nam przypuszczać, że samo używanie oparów roślinnych było w Europie znane dużo wcześniej. Europejczycy zapoznają się ze zwyczajem palenia tytoniu już w trakcie pierwszej ekspedycji Krzysztofa Kolumba. Z czasem wiadomości o nowej używce coraz częściej napływają na Stary Kontynent. Już na początku XVII w. tytoń palono i zażywano w całym ówczesnym świecie. Wśród popularyzatorów tytoniu możemy wymienić Jeana Nicota oraz Waltera Raleigha. Pierwszy z nich, będąc dyplomatą na dworze francuskim $\mathrm{z}$ misją $\mathrm{w}$ Lizbonie, podpatrzył sposób zażywania sproszkowanego tytoniu poprzez wciąganie go do nosa, a następnie rozpropagował go na dworze francuskim.
\end{abstract}


Od jego nazwiska powstała nazwa łacińska tytoniu (Nicotiana tabacum L.) oraz głównego alkaloidu, która zawiera ta roślina - nikotyna. W. Raleigh natomiast rozpowszechnił palenie fajki w angielskim środowisku dworskim. Zwyczaj ten równie szybko przyjął się w niższych warstwach społecznych. Właśnie w Anglii powstały pierwsze warsztaty produkujące fajki. Było to już pod koniec XVI w. Stamtąd fajki trafiały najpierw do Niderlandów, następnie na skutek wojny trzydziestoletniej upowszechniają się w całej Europie.

Zwyczaj używania tytoniu w Polsce pojawił się pod koniec XVI w., prawdopodobnie dzięki zawijającym do polskich portów angielskim statkom kupieckim. Do upowszechnienia tytoniu z pewnością przyczynili się wędrowni szkoccy kramarze, których w swoim wierszu z 2. poł. XVII w. opisuje Jakub Trembecki:

O brzydcy śmierdziuchowie, którzy takie smrody

Zbywacie ludziom, godni śmierdzącej nagrody,

Żeby was pod wychodki za nogi wieszano!

A jak wy na tabakę, tak też na was szczano.

Pod koniec XVII w. tytoń był niezwykle popularny wśród społeczeństwa polskiego. Zażywali go przedstawiciele wszystkich warstw społecznych. Wśród władców lubujących się w dymie tytoniowym wymienić możemy Jana III Sobieskiego oraz Stanisława Leszczyńskiego. Ten ostatni potrafił wypalić 30 fajek dziennie, dzięki czemu zyskał przydomek ,skórzanej gęby”.

W drugim rozdziale pracy przedstawiam technologię produkcji fajek. Możemy podzielić je ze względu na budowę. Wyróżnić możemy fajki jednorodne (zbudowane z jednego fragmentu gliny) oraz fajki złożone - wykonane z kilku elementów. Różnica $\mathrm{w}$ technologii produkcji fajek wynikała z różnorodności materiałów, z których je wytwarzano. W rozdziale tym opisuję etapy produkcji fajek jednorodnych i złożonych. Wśród tych ostatnich wydzielam lulki, fajki porcelanowe, sepiolitowe i drewniane. Na największą uwagę zasługuje proces produkcyjny fajek jednorodnych, m.in. ze względu na świetną organizacją produkcji, dzięki której mogły jednocześnie powstawać tysiące fajek o doskonałej jakości i niskiej cenie. Fajki jednorodne wytwarzano z glinki kaolinowej, nadając im kształt za pomocą specjalnych form. Po odpowiednim przygotowaniu surowca wstępnie formowano porcję gliny, uzyskując z grubsza przygotowany półfabrykat. Następnie przechodził on kilka etapów produkcyjnych, w trakcie których nabierał kształtu umożliwiającego włożenie do formy. Po ściśnięciu formy wywiercano otwór w główce oraz przepychano kanał dymny. Po wyjęciu z formy wygładzano szwy i poddawano fajkę dalszej obróbce mającej na celu przygotować wyrób do wypału. Fajki wypalano w temperaturze $1000^{\circ} \mathrm{C}$, w specjalnych tyglach mieszczących nawet 720 fajek.

W rozdziale trzecim pt. „Kwestie typologiczno-chronologiczne”, kończącym część wprowadzającą pracy, omawiam sposoby określania proweniencji i datowania fajek. Skupiam się tutaj na fajkach jednorodnych, które dzięki specyficznemu procesowi produkcji oraz rozwiniętemu zwyczajowi sygnowania ich przez wytwórnie, umożliwiły 
powstanie wielu charakterystycznych metod określenia chronologii i proweniencji tych zabytków. W przypadku fajek złożonych niezbyt skomplikowany proces produkcyjny oraz rzadkość sygnowania wyrobów spowodowały brak metod pozwalających precyzyjnie określić czas ich powstania. W związku z tym staram się omówić możliwość określania chronologii i proweniencji fajek złożonych w trakcie analizy tych materiałów.

Pierwsze fajki jednorodne były niewielkich rozmiarów, co związane było z ówczesną wysoką ceną tytoniu. Z czasem tytoń stał się bardziej powszechny i w związku z tym fajki stają się większe. Zmieniały się nie tylko ich gabaryty, ale również forma. Dzięki temu powstały typologie fajek najczęściej odnoszące się do konkretnych wytwórni. Ich połączenie z sygnaturami umieszczanymi na fajkach jednorodnych sprawia, że jesteśmy w stanie określić pochodzenie okazu, jak również nierzadko konkretnego wytwórcę. Sygnatury te występowały często przez pewien okres, dzięki czemu w konfrontacji z kształtem i wielkością fajki możemy uściślić czas powstania wyrobu. Fajki znajdowane podczas badań archeologicznych są w dużej mierze wyrobami zachowanymi fragmentarycznie. Znajdowane są fragmenty główek, cybuchów i ustników. W przypadku tych pierwszych możemy wyróżnić kilka metod datowania: metodę typologiczną, metodę matematyczno-typologiczną oraz typologię sygnatury „róża Tudorów” stworzoną dla fajek holenderskich. Częstszym znaleziskiem od główek fajek są fragmenty cybuchów o bogatej ornamentyce, jak również zawierające inskrypcje z nazwiskami właścicieli manufaktur lub handlarzy fajek. Dzięki tym inskrypcjom możemy w miarę precyzyjnie określać proweniencję, jak i czas wykonania fajek.

$\mathrm{W}$ rozdziale czwartym analizuję znajdowane fajki jednorodne. Analizie poddaję około 28 tysięcy fragmentów fajek znajdowanych w trakcie badań archeologicznych. Omawiając ten materiał, starałem się zachować porządek chronologiczny, rodowodowy, jak również terytorialny. W przypadku tego ostatniego było to o tyle trudne, że w tym czasie zachodnie tereny obecnej Polski nie miały ustabilizowanych granic i często w jednym stuleciu miasta, w których były znajdowane fajki, zmieniały swoją przynależność państwową. W pierwszej kolejności omawiam fajki siedemnastowieczne, dalej fajki osiemnastowieczne, a w następującej kolejności pochodzące z wytwórni holenderskich, pruskich i niemieckich, wśród których wyróżniam fajki wykonane w manufakturach w Rościnie, Zborowskiem, Weissenspringu (koło Frankfurtu n. Odrą), Zgorzelcu oraz fajki pochodzące $\mathrm{z}$ innych wytwórni niemieckich. Na koniec omawiam XVIIIi XIX-wieczne fajki angielskie. Fajki jednorodne na opracowywanych terenach pojawiają się już na początku XVII w. i są używane do późnych lat wieku XIX. Większość z nich była w XVII w. importowana z Holandii, głównie z ośrodków w Goudzie i Amsterdamie. Nieliczne fragmenty fajek produkowanych $w$ warsztatach angielskich znajdowane są w Gdańsku, co z pewnością związane jest z szerokimi kontaktami handlowymi tego miasta, które w XVII w. było jednym z największych i najbogatszych miast Europy. Inaczej przedstawia się sytuacja na terenach południowych obecnej zachodniej Polski, czyli na Śląsku, terenach należących do Saksonii oraz południowych terenach Brandenburgii, gdzie oprócz fajek pochodzenia holenderskiego znajdowane są również 
wytwory pochodzące $\mathrm{z}$ warsztatów działających najprawdopodobniej we wschodniej Saksonii lub na Śląsku. Fajki zaczęto tam wytwarzać na wzór okazów holenderskich i angielskich, ale bez znajomości poszczególnych etapów produkcji. Interesujące jest to, że stanowią one aż 87\% wszystkich zidentyfikowanych fragmentów jako pozostałe 13\% są to fajki pochodzenia holenderskiego, w większości znalezione we Wrocławiu. Od początku XVIII w. dominują wytwory z Goudy, największego ośrodka produkującego fajki jednorodne. W połowie wieku XVIII funkcjonowało tam 500 warsztatów zatrudniających około 7000 ludzi, co stanowiło 1/3 mieszkańców ówczesnej Goudy. Trudno jest oszacować liczbę produkowanych wówczas fajek, ale musiały być to miliony sztuk rocznie. W 2. poł. XVIII w. producenci z Goudy zmuszeni byli rywalizować o rynki zbytu z miejscowymi wytwórcami. Powstają wówczas manufaktury w Rościnie, Weissenspringu i Zborowskiem. Dwie pierwsze przejmują rynki głównie na północy, natomiast wytwory ze Zborowskiego sprzedawane były na terenie Śląska. Dopiero w trakcie zbierania materiałów i ich analizowania udało mi się zidentyfikować zespół fajek pochodzący ze Zgorzelca, który nie pasował do wyrobów ze wspomnianych wcześniej wytwórni. W trakcie przeprowadzonych przeze mnie studiów okazało się, że fajki te pochodzą z małej rodzinnej wytwórni zlokalizowanej na Przedmieściach Nyskich w Görlitz (dzisiejszy Zgorzelec). Wytwórnia ta znana była dotychczas tylko z materiałów archiwalnych. Dzięki przypadkowemu odkryciu w Zgorzelcu mogliśmy się zapoznać z jej asortymentem.

Większość fajek jednorodnych znajdowanych w trakcie badań archeologicznych jest gładka i nie ma specjalnych zdobień. Zdarzają się jednakże fajki zdobione. Wśród takich okazów opracowywanych w tej pracy na szczególną uwagę zasługuje fajka znaleziona w Lwówku Śląskim, zdobiona popiersiami Wilhelma IV Orańskiego i jego żony Anny Hanowerskiej. Fajki takie były produkowane w warsztatach holenderskich i były wyrazem poparcia społeczeństwa dla dynastii Oranie. Znaleziska takich fajek poza terenem Holandii są rzadkością. Co ciekawe w okolicach Lwówka Śląskiego znaleziono jeszcze jeden egzemplarz fajki o takiej samej estetyce, na którym widnieją popiersia pary książęcej Karola Christiana Nassau-Weilburg i Karoliny Oranie-Nassau. Ze względu na odkrycie omawianego okazu tegorocznego lata, czyli już po zakończeniu pisania tej pracy, nie udało mi się go dołączyć do niniejszej dysertacji.

W rozdziale piątym analizuję fajki złożone. Jest ich o wiele mniej niż fajek jednorodnych - tylko 442 fragmenty. Są to przede wszystkim lulki i fajki porcelanowe. Lulki, czyli fajki trzyczęściowe, zbudowane z główki, cybucha oraz ustnika pojawiają się w Polsce w 2. poł. XVII w. Cybuchy tego typu fajek najczęściej były kupowane osobno albo dorabiane według własnego uznania. Najczęściej osiągały długość od 15 do $30 \mathrm{~cm}$, chociaż niektóre mogły osiągać nawet $2 \mathrm{~m}$ długości. Wykonywano je najczęściej z drewna, natomiast ustniki mogły być wykonane z bursztynu, rogu bydlęcego, metalu, egzotycznego drewna, ceramiki i kamieni półszlachetnych. Fajki te pojawiają się w Europie dzięki wpływom tureckim. Główki tych fajek były wyrabiane z gliny. Miały masywniejszą od fajek jednorodnych budowę, były więc trwalsze i mogły dłużej służyć. 
Lulki były dużo prostsze do wykonania niż fajki jednorodne, można je było produkować w zwykłych pracowniach garncarskich. Często też wykonywano takie fajki na własny użytek. Dlatego też bardzo trudno jest określić ich pochodzenie i chronologię. Przy obecnym stanie badań trudno jest ustalić typologię kształtów lulek, która pomogłaby w datowaniu tych zabytków. Kształty tych fajek często ulegały zmianom i modyfikacjom, które miały przyciągnąć klientów.

Fajki porcelanowe zbudowane były z czterech części: główki, osadnika na kondensat, cybucha i ustnika. Tego rodzaju fajki stają się popularne w XIX w. Z części składowych fajek najczęściej znajdowane są główki i osadniki, czasami również w trakcie prac archeologicznych można pozyskać kapturki. Podobnie jak w przypadku lulek trudno jest precyzyjnie określić czas i miejsce powstania fajek porcelanowych, co związane jest z rzadkim umieszczaniem przez manufaktury sygnatur na tego rodzaju wyrobach. Wyjątkowymi zabytkami porcelanowymi są fajki rezerwistów. Takie fajki były wręczane żołnierzom odchodzącym do rezerwy w wojsku niemieckim i austriackim. Główki fajek rezerwistów są bogato zdobione scenkami rodzajowymi związanymi z życiem żołnierza, przedstawieniami militarnymi czy podobiznami sławnych wodzów. Oprócz takich zdobień na fajkach rezerwistów znajdują się często dedykacje przeznaczone dla właściciela, wymieniane są często również odznaczenia zdobyte przez żołnierza oraz imiona i nazwiska kolegów służących razem z nim w wojsku. Oprócz okazów nawiązujących zdobieniem do fajek rezerwistów na terenach opracowywanych przeze mnie znajdowane były główki dekorowane przedstawieniami kwiatowymi, scenkami myśliwskimi, przedstawieniami kobiet, krajobrazami, reprodukcjami obrazów, panoramami miast, herbami oraz scenkami rodzajowymi.

W rozdziale szóstym opisuję handel fajkami i tytoniem. Fajki z warsztatów holenderskich docierają w fasach, beczkach, koszach i skrzyniach przez porty w Gdańsku, Elblągu, Kołobrzegu i Szczecinie. W XVII w. pojawiają się pierwsze nazwiska wytwórców holenderskich eksportujących fajki na tereny obecnej zachodniej Polski. Z 1. poł. XVII w. możemy wymienić czterech wytwórców z Amsterdamu: Everta Birda, Jacoba Adamsa, Jana Atfoorta oraz Mathiasa Staforda; natomiast w 2. poł. XVII w. są to producenci z Goudy: Cornelis Jansz de Vriendt, Jan Wilemsz Bruggen oraz Cornelis Dirksz Peck. W XVIII w. największymi eksporterami na tereny przeze mnie opisywane byli: Machiel Brem, Hendrick Manshoofd, Lucas de Jong, Jacob de Vos, warsztat rodziny Danens i Frans Verzijl. Oprócz wymienionych producentów specyficzną rolę na rynku fajkarskim spełniali kupcy fajek. Oprócz tradycyjnego nabywania towaru na rynku fajek część z nich zamawiała towar bezpośrednio u producentów, współpracując z nimi na tyle ściśle, że ich nazwiska pojawiają się na cybuchach. Z terenów przeze mnie opisywanych warto wymienić następujących kupców, którzy są znani z inskrypcji na cybuchach: Georga Mosesa, Dircka Entvogela oraz Jacuba i Fransa van der Velde. Fajki tych wytwórców dominowały do pierwszych lat 2. poł. XVIII w. W drugiej połowie wieku dużą konkurencją dla tych wyrobów stają się fajki produkowane w pruskich manufakturach: Rościnie, Weissenspringu i Zborowskiem. 
Handel tytoniem od początku jego pojawienia był bardzo dochodowym interesem. Świadczą o tym między innymi uchwały rządowe państw europejskich traktujące go jako surowiec strategiczny dla ówczesnych budżetów państwowych. Dowody na możliwości szybkiego wzbogacenia się na handlu tym towarem możemy znaleźć w inwentarzach poznańskich mieszczan, gdzie od 1710 do 1776 r. wyszczególnione jest ponad 5 ton przeróżnych wyrobów tytoniowych o wartości prawie 10000 ówczesnych złotych. Taka kwota starczyłaby na zakup kamienicy w ówczesnym Poznaniu, a przecież jest to znikoma część towaru, który w tym czasie sprzedawano w tym mieście.

W ostatnim rozdziale staram się przedstawić kulturę zażywania tytoniu. W jaki sposób ta egzotyczna używka zyskała tak dużą popularność wśród Europejczyków, stając się powszechną we wszystkich warstwach społecznych. Najprawdopodobniej przy rozpowszechnieniu tytoniu służyły właściwości lecznicze, które wówczas jemu przypisywano. Tytoń był uważany za niemal panaceum. Wierzono, że pomaga na bóle głowy, katar, bóle w piersiach, gruźlicę, syfilis, zatwardzenie, bóle brzucha i wiele innych dolegliwości. Równie szybko pojawiają się ostre słowa krytyki związane z zagrożeniami, jakie może wywołać nadużywanie tytoniu. Mimo nakładania ogromnych podatków na tę używkę, jej popularność niesłabnie. Przyczyniało się do tego to, że zażywanie tytoniu dawało uczucie komfortu psychicznego i relaksu, co wywoływało dobre samopoczucie. Przede wszystkim jednak palenie zmniejszało uczucie głodu. Tytoń podbił świat dzięki formie jego konsumpcji, czyli paleniu. Żaden inny sposób jego zażywania nie dostarczał nikotyny do krwioobiegu tak szybko.

$\mathrm{Na}$ terenach obecnych zachodnich ziem polskich pojawia się na początku XVII w. zwyczaj używania tytoniu w fajkach jednorodnych. Już w 1. poł. tego wieku palenie zadomowiło się jako konieczność dnia codziennego, błyskawicznie przekraczając wszystkie granice społeczne. Samo przygotowanie do palenia stało się rytuałem polegającym na skrobaniu, czyszczeniu, ubijaniu i rozpalaniu tytoniu. Już w 2. poł. XVII w. pojawiają się za pośrednictwem Turcji fajki złożone. Fajki te stwarzały użytkownikom większą możliwość wyboru długości cybucha i sposobu palenia. Biedniejsza część palaczy wybierała proste główki wyprodukowane w miejscowym warsztacie garncarskim oraz tańszy, krótki cybuch, który pozwalał delektować się tytoniem również w czasie pracy. Bogatsi palacze natomiast wybierali bogato zdobione główki i długie cybuchy z bursztynowymi ustnikami. Mimo tej nowości przez całą 2. poł. XVII i XVIII w. fajki jednorodne nadal cieszyły się ogromną popularnością, głównie dzięki bardzo niskiej cenie. Nie bez znaczenia było nowe wzornictwo, powiększająca się główka i wydłużający się cybuch. Na początku XVIII w. pojawiają się fajki wykonane z sepiolitu zwanego również pianką morską. Przybywają one z terenów będących pod panowaniem tureckim. Dzięki właściwościom tego materiału powstają fajki z bajecznymi zdobieniami, często będącymi miniaturowymi dziełami sztuki. Ze względu na cenę fajki te stają się popularne głównie w zamożniejszych warstwach społecznych. Z fajek z pianki morskiej korzystała arystokracja, szlachta, ale również bogatsi mieszczanie. Przez cały XVIII w., a nawet na początku XX w. wszystkie omawiane wyżej fajki są nadal w użyciu. 
W 2. poł. XVIII w. dołączają do nich jeszcze fajki porcelanowe, które szczególnie stają się modne w XIX w. Charakteryzują się one bogatym zdobnictwem, które dotyczy nie tylko główki (dominują przede wszystkim krajobrazy, symbole profesji, scenki rodzajowe czy wybitne postacie), ale również cybucha (wykonywanego głównie z drewna, zdobionego na całej długości, osiągającego często $1 \mathrm{~m}$ lub więcej). Tak długie fajki wymagały odpowiedniego rytuału i miejsca użytkowania. W domach wydzielano specjalne pokoje wyposażone w charakterystyczny sprzęt, tzw. fajczarnie, czyli specjalne oprzyrządowanie służące do ustawiania fajek. Na początku XIX w. pojawiają się fajki wykonane z korzenia wrzośca, które z czasem wypierają z rynku fajki z innych materiałów.

W XVIII w. na terenie obecnych zachodnich ziem polskich upowszechnia się inny zwyczaj zażywania tytoniu, a mianowicie wciąganie sproszkowanej jego formy przez nos, preferowany po części także dlatego, że wąchając, zużywa się mniej tytoniu niż przy paleniu. Zażywanie tabaki staje się bardzo popularne w modnych kręgach towarzyskich, a następnie upowszechnia się wśród reszty społeczeństwa. Kosztowne i pięknie zdobione tabakiery $\mathrm{z}$ tego okresu $\mathrm{w}$ równym stopniu stanowiły symbol statusu społecznego, co pełniły praktyczną funkcję pojemnika. Na początku XIX w. zażywanie tabaki wychodzi z mody na rzecz popularniejszego $w$ tym czasie palenia cygar i pojawiających się w 2. poł. XIX w. papierosów. Jednak na terenach przeze mnie opisywanych zwyczaj ten pozostał na Kaszubach i Kociewiu, gdzie zażywanie tabaki stało się ważnym obyczajem kultury ludowej tych regionów.

Opracowanie całokształtu problemów związanych z fajkami i zażywaniem tytoniu było zadaniem trudnym. Spowodowane to było dostępnością materiałów, jak i brakiem szczegółowej literatury ujmującej znaleziska fajkarskie z tego terenu. Dotychczasowy stan badań nad kulturą zażywania tytoniu w Polsce pozostaje ciągle niezadowalający. Niemniej jednak znajdowane w trakcie badań archeologicznych fajki są bardzo cennym identyfikatorem nowożytnych warstw archeologicznych. Jak możemy zauważyć, w fajkach ukrytych jest wiele informacji przybliżających obraz minionej rzeczywistości. $\mathrm{W}$ związku z tym konieczne jest szerokie spojrzenie na wszelkie informacje zakodowane w tym, jakby się mogło wydawać, niepozornym przedmiocie codziennego użytku.

PIPES AND TOBACCO USE IN WESTERN AREAS OF PRESENT-DAY POLAND IN THE PERIOD BETWEEN THE 17TH AND THE BEGINNING OF 20TH CENTURY

$$
\text { S u m m a r y }
$$

Clay pipes are common category of archaeological data. These are very interesting and useful artifacts. In most cases, their chronological position and the place of origin are easy to determine. The first clay pipes appeared in the western areas of present-day Poland in the beginning of the $17^{\text {th }}$ century. They were made by pipe makers from Amsterdam and Gouda City (Holland). In the second half of the $17^{\text {th }}$ century in southern part of western areas of present-day Poland or in their neighbourhood, local manufactures producing clay pipes for local market - Śląsk, eastern 
Saksonia and southern Branderburgia, were established. The products from Gouda were the most popular in the first half of the $18^{\text {th }}$ century. Machiel Brem, Hendrick Manshoofd, Lucas de Jong, Jacob de Vos, Danens' Family manufacture and Frans Verzijl were among their biggest exporters to western areas of present-day Poland. From the second half of the $18^{\text {th }}$ century, the pipe makers from Gouda had to compete with products of local manufactures, such as Rościn, Zborowskie and Weissenspring. Stub-stemmed pipes came to western areas of present-day Poland from Turkey around the middle of the $17^{\text {th }}$ century. It is worth mentioning that drawing snuff was very popular in the western areas of present-day Poland in the $18^{\text {th }}$ century, but cigars and cigarettes became more popular only in the following centuries.

\section{Eukasz Gil}

Instytut Prahistorii, Uniwersytet im. Adama Mickiewicza ul. Św. Marcin 78, 61-809 Poznań, Poland 